\title{
THE AMINO ACID AND MONOSACCHARIDE COMPOSITION OF A DRY EXTRACT FROM SALVIA OFFICINALIS LEAVES OBTAINED BY COMPLEX PROCESSING
}

\author{
G.V.Vovk, O.M.Koshovyi, A.M.Komissarenko \\ National University of Pharmacy
}

Key words: Salvia officinalis; leaves; dry extract; amino acid; monosaccharide; complex processing

The amino acid and monosaccharide composition of a dry extract from Salvia officinalis leaves obtained by complex processing has been studied. The preliminary determination of amino acids and monosaccharides has been performed by paper chromatography. The qualitative and quantitative analysis of free and bound amino acids and monosaccharides in the extract from Salvia officinalis leaves has been carried out using a high performance liquid chromatograph by Agilent Technologies company (model 1100) equipped with a flow vacuum degasser G1379A, a 4-channel pump of the low pressure gradient $G 13111 A$, an automatic injector $G 1313 A$, a column thermostat $G 13116 A$, diode array detector G1316A. As a result of the chromatographic studies of the amino acid and monosaccharide composition in the dry extract from Salvia officinalis leaves 10 free and 12 bound amino acids have been identified, six of which are indispensable - threonine, valine, isoleucine, leucine, phenylalanine and arginine, and 4 monosaccharides - glucose, galactose, rhamnose and arabinose. In the extract of Salvia officinalis leaves dominant substances are tyrosine, serine, glutamic and aspartic acid. In the dry extract of Salvia officinalis leaves the content of free $(0.38 \%)$ and bound $(0.43 \%)$ amino acids, monosaccharides (6.9\%) increasing up to $11.2 \%$ after hydrolysis has been determined.

The problem of the rational use of the medicinal plant raw material (MPRM) by the pharmaceutical industry attracts more and more attention. Industrial waste products are tons of the extraction pomace containing a significant amount of biologically active substances and can be used to create new medicines. Despite the limited natural resources, the task of the modern pharmaceutical industry is development of methods for complex processing of MPRM allowing maximum use of its capabilities.

More than 40 drugs, which include biologically active substances (BAS) of Salvia officinalis leaves, have been registered at the market of Ukraine [3]. The composition of these drugs mainly includes the essential oil and tincture from the leaves of Salvia officinalis, i.e. the complex of lipophilic substances [3, 10, 11]. Previously the domestic pharmaceutical industry produced "Salvine" $1 \%$ alcoholic solution of the acetone extract from Salvia officinalis leaves. Since later acetone was attributed to precursors, manufacturers discontinued the production of this drug, and "Salvine" disappeared from pharmacy shelves despite the efficiency of its use for the treatment of infectious and inflammatory diseases of the oral cavity. Acetone largely extracts substances of the terpenic origin (mono-, sesqui- and diterpenes), while the extraction pomace still contains more polar substances, in particular of the phenolic nature, amino acids and sugars $[1,4,9]$. In reference with the abovementioned facts, the method of complex processing of this raw material with obtaining the dry extract possessing the anti-inflammatory action has been developed $[4,5,12]$.

Since amino acids and monosaccharides have a significant impact on bioavailability and the total therapeutic effect of the extract, the aim of our further studies is to investigate the amino acid and sugar composition of the dry extract from Salvia officinalis leaves obtained.

\section{Materials and Methods}

The object of the study was a dry aqueous extract of Salvia officinalis leaves obtained by complex processing [5]. The analysis of the extract was carried out according to the requirements of the SPhU $[2,6]$.

The preliminary chromatographic study of the qualitative composition of amino acids in a dry extract of Salvia officinalis leaves was conducted by the method of ascending chromatography on a "Filtrak No. 4" chromatography paper in the system of $n$-butanol - acetic acidwater $(4: 1: 2)[1,9]$. For comparison the standard set of amino acids (TU 6-09-3147-83) in the concentration of $0.1 \%$ was used. Chromatograms were treated with $0.2 \%$ ninhydrin solution in acetone and dried in a drying cabinet at a temperature of $60-80^{\circ} \mathrm{C}$. Amino acids were identified comparing with authentic samples of $R_{f}$ values in parallel chromatographic procedure.

The qualitative composition and quantitative content of free and bound amino acids and monosaccharides in the extract from Salvia officinalis leaves was carried out using a high performance liquid chromatograph by Agilent Technologies company (model 1100) equipped with a flow vacuum degasser G1379A, a 4-channel pump of the low pressure gradient G13111A, an automatic injector G1313A, a column thermostat G13116A, diode array detector G1316A [7, 8].

For chromatography we used: column AA with the size of $200 \times 2.1 \mathrm{~mm}$ and a guard column; as a mobile phase - solution A (20 mM of sodium acetate and $0.018 \%$ triethylamine adjusted to $\mathrm{pH} 7.2$ with $1-2 \%$ acetic acid) with addition of $0.3 \%$ tetrahydrofuran, and solution $\mathrm{B}$ 
Table

The amino acid composition of the dry extract from Salvia officinalis leaves

\begin{tabular}{|l|c|c|}
\hline \multirow{2}{*}{\multicolumn{1}{|c|}{ Amino acid }} & \multicolumn{2}{|c|}{$\begin{array}{c}\text { The content of amino acids } \\
\text { (mg per 100 g of a dry extract) }\end{array}$} \\
\cline { 2 - 3 } & Free & Bound \\
\hline Aspartic acid & 23.4 & 53.1 \\
\hline Glutamic acid & 26.6 & 44.2 \\
\hline Serine & 87.4 & 94.1 \\
\hline Valine & 8.1 & 18.4 \\
\hline Arginine & 0.0 & 7.1 \\
\hline Glycine & 4.4 & 4.7 \\
\hline Threonine & 9.2 & 21.1 \\
\hline Phenylalanine & 18.0 & 23.5 \\
\hline Isoleucine & 15.4 & 28.2 \\
\hline Leucine & 20.1 & 21.7 \\
\hline Cysteine & 0.0 & 51.9 \\
\hline Tyrosine & 164.0 & 62.5 \\
\hline
\end{tabular}

$\left(40 \% \mathrm{CH}_{3} \mathrm{CN}, 40 \% \mathrm{MeOH}\right.$ and $20 \%$ of sodium acetate adjusted to $\mathrm{pH} 7.2$ with $1-2 \%$ acetic acid); the volume flow rate $-0.450 \mathrm{ml} / \mathrm{min}$; the compressibility of solution $\mathrm{A}-$ $50 \cdot 10^{-6}$ Bar, solution $\mathrm{B}-115 \cdot 10^{-6} \mathrm{Bar}$; the column temperature $-40^{\circ} \mathrm{C}$; detection was performed using an $\mathrm{UV}$ detector.

The sample preparation for studying the composition of free amino acids. In a $10 \mathrm{ml}$ vial (A) add $0.3 \mathrm{ml}$ of the extract. Then pour $3 \mathrm{ml}$ of $0.1 \mathrm{~N}$ aqueous solution of hydrochloric acid containing $0.2 \% \beta$-mercaptoethanol into the vial. Close the vial hermetically and place in an ultrasonic bath for $2 \mathrm{~h}$ at the temperature of $50^{\circ} \mathrm{C}$.

The sample preparation for studying the total content of amino acids. In a vial (B) add $0.20 \mathrm{ml}$ of the extract. Then pour $3 \mathrm{ml}$ of $6 \mathrm{~N}$ aqueous solution of hydrochloric acid containing $0.4 \% \beta$-mercaptoethanol into the vial. Close the vial hermetically and keep for $24 \mathrm{~h}$ at the temperature of $110^{\circ} \mathrm{C}$.

Centrifuge and filter the vial with samples. Collect the filtrates into reaction vials: $100 \mu \mathrm{l}$ from vial A and $20 \mu \mathrm{l}$ from vial B, place in a vacuum desiccator at a temperature of $40-45^{\circ} \mathrm{C}$ and pressure of $1.5 \mathrm{~mm} \mathrm{Hg}$ and keep to complete removal of hydrochloric acid. Then into the vial for analysis successively add $200 \mu \mathrm{l}$ of $0.8 \mathrm{M}$ borate buffer with $\mathrm{pH} 9.0,200 \mu \mathrm{l}$ of $20 \mathrm{mM}$ solution of 9-fluorenylmethoxycarbonyl chloride in acetonitrile with an automatic injector, after a $10 \mathrm{~min}$ exposure into the reaction vial add $20 \mu \mathrm{l}$ of $150 \mathrm{mM}$ solution of amantadine hydrochloride in $50 \%$ water acetonitrile $[7,8]$.

Identification of amino acids was performed by retention time of standards. Calculation of the content of bound amino acids was carried out by subtracting the content of free amino acids from their total content.

The preliminary identification of monosaccharides was performed using paper chromatography by the descending method in the system of $n$-butanol - acetic acid water (4:1:2) with authentic samples of neutral monosaccharides. Chromatograms were developed with the solution of aniline phthalate.

The analysis of sugars was carried out using a chromatograph by Agilent Technologies company (model 1100) equipped with a flow vacuum degasser G1379A, a 4-channel pump of the low pressure gradient G13111A, an automatic injector G1313A, a column thermostat G13116A, refractometric detector G1316A. To carry out the analysis a "Supelcogel-C610H" carbohydrate chromatographic column with the size of $7.8 \times 300 \mathrm{~mm}$ was used, and the following chromatographic mode was set: the rate of the mobile phase supply $-0.5 \mathrm{ml} / \mathrm{min}$, eluent $-0.1 \%$ aqueous solution of $\mathrm{H}_{3} \mathrm{PO}_{4}$, working pressure of the eluent $-33-36 \mathrm{kPa}$, the temperature of the thermostat column $-30^{\circ} \mathrm{C}$, the sample volume $-5 \mu$ l. Parameters of refractometric detection were as follows: the scale of measurement -1.0 , the scan time $-0.5 \mathrm{~s}$. Identification of sugars was carried out according to the retention time of standards.

To analyze bound sugars the acid hydrolysis was carried out according to the following procedure. Into a $5 \mathrm{ml}$ glass vial introduce $400 \mathrm{mg}$ of the extract (accurate weight) add $5 \mathrm{ml}$ of $6 \mathrm{M}$ solution of hydrochloric acid. After that close the vial hermetically and keep for $24 \mathrm{~h}$ at the temperature of $100^{\circ} \mathrm{C}$ in the oven. After cooling centrifuge and filter the vial content through a teflon membrane filter with the pore size of $0.45 \mu \mathrm{m}$ into a vial for analysis.

\section{Results and Discussion}

Using the paper chromatography method, four amino acids have been determined in the extract.

The results of determination of the qualitative composition and quantitative content of free and bound amino acids in the dry extract of Salvia officinalis leaves obtained by complex processing using HPLC are presented in Table.

As a result of studying the amino acid composition of the dry extract from Salvia officinalis leaves 10 free and 12 bound amino acids have been identified, six of them are indispensable - threonine, valine, isoleucine, leucine, phenylalanine and arginine. As can be seen from Table, in the extract of Salvia officinalis leaves dominant substances are tyrosine, serine, glutamic and aspartic acid. The content of free amino acids is $0.38 \%$, and the content of bound amino acids is $0.43 \%$.

Glucose and galactose, and after hydrolysis arabinose, have been identified in the extract.

As a result of determination of the qualitative composition and quantitative content of sugars in the dry extract from Salvia officinalis leaves by HPLC four monosaccharides such as glucose, galactose and rhamnose, and after hydrolysis arabinose, have been identified. The content of monosaccharides in the dry extract from Salvia officinalis leaves is $6.9 \%$, and after hydrolysis it increases up to $11.2 \%$.

\section{CONCLUSIONS}

The amino acid and monosaccharide composition of a dry extract from Salvia officinalis leaves obtained by complex processing has been studied; in particular, 10 free and 12 bound amino acids have been identified, six of them are indispensable - threonine, valine, isoleucine, leucine, phenylalanine and arginine, and 4 monosaccharides - glucose, galactose, rhamnose and arabinose.

In the dry extract of Salvia officinalis leaves the content of free $(0.38 \%)$ and bound $(0.43 \%)$ amino acids, monosaccharides $(6.9 \%)$ increasing up to $11.2 \%$ after hydrolysis has been determined. 


\section{REFERENCES}

1. Вовк Г.В., Комовий О.М., Комісаренко А.М. // Зб. наук. пращь співроб. НМАПО ім. П.Л.Шупика. - 2014. №4. - C. 237-240.

2. Держсавна фармакопея Украйни / Державне підприємство «Науково-експертний фармакопейний центр». 1-е вид. - Доп. 2. - Х.: ДП «Науково-експертний фармакопейний ичентр», 2008. - 620 c.

3. Компендиум 2014 - лекарственные препараты / Под ред. В.Н.Коваленко. - К.: МОРИОН, 2014. - 2700 с.

4. Кочевой О.Н., Вовк Г.В., Ахмедов Э.Ю. и др. // Азербайджанский фармац. и фармакотерапевт. журн. 2015. - №1. - C. 30-34.

5. Пат. України на корисну модель № 92310, МПК А 61 К 36/537, А 61 Р 31/00. Спосіб одержання засобу з листя шавлії лікарської з антимікробною та протизапальною активністю / Г.В.Вовк, О.М.Кочовий, А.М.Ковальова, В.А.Рибак, А.М.Комісаренко, М.М.Мига. - № и 2014 02605. Заявл.: 14.03.2014. Опубл.: 11.08.14. - Бюл. №15. - 4 c.

6. European Pharmacopoeia. - 4-th ed. - Strasbourg: Council of Europe, 2001. - 2416 p.

7. Jámbor A., Molnár-Perl I. // J. of Chromatography A. - 2009. - Vol. 1216. - P. 3064-3077.

8. Jámbor A., Molnár-Perl I. // J. of Chromatography A. - 2009. - Vol. 1216. - P. 6218-6223.

9. Velickovic A.L., Smelecerovic A.A., Randjelovic N.V. et al. // J. Serb. Chem. Soc. - 2003. - Vol. 68, №1. - P. 57-63.

10. WHO monographs on selected medicinal plants: - Geneva: World Health Organization, 2002. - Vol. 2. - 586 p.

11. Yinrong Lu, Foo L. Yeap. // Phytochemistry: The Intern. J. of Plant Biochemistry. - 1999. - Vol. 51, №1. - P. 57-63.

12. Yudicheva D.M., Vovk G.V., Koshoviy O.M. // Topical issues of new drugs development. - 2015. - P. 109-110.

\section{АМІНОКИСЛОТНИЙ ТА МОНОЦУКРОВИЙ СКЛАД СУХОГО ЕКСТРАКТУ 3 ЛИСТЯ ШАВЛІЇ ЛІКАРСЬКОЇ, ОТРИМАНОГО ШЛЯХОМ КОМПЛЕКСНОЇ ПЕРЕРОБКИ \\ Г.В.Вовк, О.М.Кошовий, А.М.Комісаренко \\ Ключові слова: шавлія лікарська; листя; сухий екстракт; амінокислота; моноцукор;} комплексна переробка

Досліджено амінокислотний та моноцукровий склад сухого екстракту листя шавлії лікарської, одержаного шляхом комплексної переробки. Попереднє виявлення амінокислот та моноцукрів проводили методом паперової хроматографрії. Якісний склад та кількісний вміст вільних та зв'язаних амінокислот та моноцукрів у екстракті з листя шавлії лікарської проводили за допомогою високоефективного рідинного хроматографра фрірми Agilent Technologies (модель 1100), укомплектованого проточним вакуумним дегазатором G1379A, 4-и канальним насосом градієнта низького тиску G13111A, автоматичним інжектором G1313A, термостатом колонок G13116A, діодноматричним детектором G1316A. В результаті хроматографрічного дослідження амінокислотного та моноцукрового складу сухого екстракту листя шавлії лікарської ідентифріковано 10 вільних та 12 зв'язаних амінокислот, шість з яких є незамінними - треонін, валін, ізолейцин, лейцин, фенілаланін і аргінін, та 4 моноцукри - глюкоза, галактоза, рамноза та арабіноза. В екстракті листя шавлії лікарської домінуючими амінокислотами є тирозин, серин, глутамінова та аспарагінова кислоти. В сухому екстракті листя шавлії лікарської встановлено вміст вільних (0,38\%) та зв'язаних амінокислот (0,43\%), моноцукрів (6,9\%), вміст яких після гідролізу збільшується до $11,2 \%$.

\section{АМИНОКИСЛОТНЫЙ И МОНОСАХАРИДНЫЙ СОСТАВ СУХОГО ЭКСТРАКТА ИЗ ЛИСТЬЕВ} ШАЛФЕЯ ЛЕКАРСТВЕННОГО, ПОЛУЧЕННОГО КОМПЛЕКСНОЙ ПЕРЕРАБОТКОЙ

Г.В.Вовк, О.Н.Кошевой, А.Н.Комиссаренко

Ключевые слова: шалфей лекарственный; листья; сухой экстракт; аминокислота; моносахариды; комплексная переработка

Исследован аминокислотный и моносахаридный состав сухого экстракта из листьев шалфея лекарственного, полученного путем комплексной переработки. Предварительное определение аминокислот и моносахаридов проведено методом бумажной хроматографиии. Качественный состав и количественное содержание свободных и связанных аминокислот и моносахаридов в экстракте из листьев шалфея лекарственного проводилось с помощью высокоэфрфрективного жидкостного хроматографра фрирмы Agilent Technologies (модель 1100), укомплектованного проточным вакуумным дегазатором G1379A, 4-х канальным насосом градиента низкого давления G13111A, автоматическим инжектором G1313A, термостатом колонок G13116A, диодноматричным детектором G1316A. В результате хроматографического исследования аминокислотного и моносахаридного состава сухого экстракта листьев шалфрея лекарственного идентифицировано 10 свободных и 12 связанных аминокислот, шесть из которых являются незаменимыми - треонин, валин, изолейцин, лейцин, фенилаланин и аргинин, и 4 моносахарида - глюкоза, галактоза, рамноза и арабиноза. В экстракте листьев шалфрея лекарственного доминирующими веществами являются тирозин, серин, глутаминовая и аспарагиновая кислоты. В сухом экстракте листьев шалфея лекарственного установлено содержание свободных (0,38\%) и связанных аминокислот (0,43\%), моносахаридов (6,9\%), содержание которых после гидролиза увеличивается до $11,2 \%$. 